\title{
Prepless Direct Midline Diastema Closure in a Single Visit: 18 months Follow-up Report
}

\author{
Orta Hat Diastemasının Tek Seansta Preparasyonsuz Tedavisi: 18 Aylık Takip Raporu
}

Ezgi TÜTER ${ }^{1} \oplus$, Bora KORKUT' ${ }^{1}$, Pınar YILMAZ ATALI ${ }^{1} \oplus$, Cafer TÜRKMEN $^{1} \oplus$

\begin{abstract}
Maxillary midline (major) diastemas, which are common aesthetic problems for the patients may frequently occur due to high frenulum junctions. Direct prepless composite resin restorations can be economical and successful after the treatment of abnormal frenum. The present paper reports a case of maxillary major diastema due to high frenulum, which was treated with noninvasively direct composite resin restorations after frenectomy and office bleaching procedures. The success of the final restorations were assessed in 3 month, 9 month and 18 month follow ups.

Keywords: Aesthetic dentistry, midline diastema, prepless restoration

\section{Öz}

Hastalar için yaygın estetik problemlerden biri olan maksiller orta hat diastemaları, yüksek frenulum bağlantısı kaynaklı oluşabilir. Direk preparasyonsuz kompozit rezin restorasyonlar, normal olmayan frenum bağlantısı tedavisinden sonra ekonomik ve başarılı olabilir. Bu yayında, yüksek frenulum nedeniyle meydana gelen bir maksiller majör diastema vakası bildirilmiştir. Diastema, frenektomi ve ofis tipi beyazlatma prosedürlerinden sonra invaziv olmayan direkt kompozit rezin restorasyonları ile tedavi edilmiştir. Restorasyonların başarısı 3 ay, 9 ay ve 18 ay takiplerinde değerlendirilmiştir.

Anahtar kelimeler: Estetik Diş Hekimliği, orta hat diasteması, preparasyonsuz restorasyon
\end{abstract}

Ezgi Tüter (凶)

${ }^{1}$ Department of Restorative Dentistry, Faculty of Dentistry, Marmara University, Istanbul, Turkey

e-mail:

Bora Korkut, Pınar Yılmaz Atalı, Cafer Türkmen

${ }^{1}$ Department of Restorative Dentistry, Faculty of Dentistry, Marmara University, Istanbul, Turkey

Submitted / Gönderilme: 26.11.2018

Accepted/Kabul: 14.05.2019

\section{Introduction}

Aesthetic outlook has become as important as function and phonation with increasing social awareness. Midline (major) diastema is one of the reasons of aesthetic problems for the patients. The etiology is usually multifactorial such as labial frenulum, microdontia, mesiodens, dental malformations and genetic factors. Treatment options for rehabilitation of these unwilling spaces are more varied with the recent developments in adhesive dentistry. In today's dentistry, the diastemas can be closed permanently and aesthetically with direct composite resins without any preparations.

\section{Methods}

In this case report, a 23-year-old male patient applied to Marmara University Faculty of Dentistry, Department of Restorative Dentistry Clinic. According to the clinical examinations, a major diastema due to high frenulum junction was considered (Figure 1,2). As having no contraindications, treatment plan was considered as the following procedures respectively: frenectomy, office bleaching and directprepless diastema closure with composite resin.

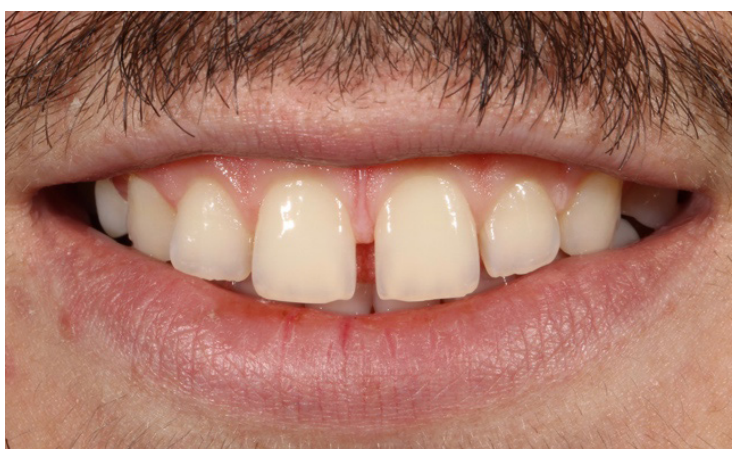

Figure 1. Initial 


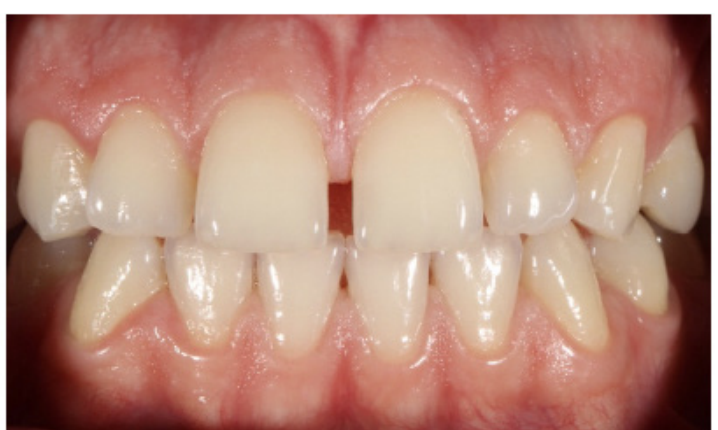

Figure 2. Initial

At the first appointment, frenectomy operation was planned to solve the reason of the midline diastema and the operation was done in Department of Periodontology, Faculty of Dentistry, Marmara University. Periodontal tissue healing was completed in six weeks. Three sessions of vital office bleaching, 20 minutes for each, was done with 40\% hydrogen peroxide gel (Opalescence Xtra Boost, Ultradent, USA). Restorative treatment was arranged two weeks after the vital bleaching (Chemical composition of the materials were shown in Table 1). Firstly, the most proper shades of a supranano spherical inorganic filler containing resin composite, were selected by using the 'Button Technique' and selected as 'A1B' and 'NE' shades (Estelite Asteria, Tokuyama Dental, Japan) (Figure 3,4). After isolation with rubber dam (Figure 5), the whole enamel surfaces were etched selectively with $36 \%$ phosphoric acid (DeTrey Conditioner 36, Dentsply, Germany) for 30 seconds, rinsed and slightly dried. Following that an universal adhesive agent (Universal bond, Kuraray Noritake, Japan) was applied to the etched surfaces and polymerized for 20 seconds with a LED polymerization unit (Valo, Ultradent, USA). A specific anterior transparent matrix system (CoForm Strips, Directa, Sweden) was used to create the emergence profiles of the restorations ${ }^{14}$ (Figure 6). 'NE' shade resin was used for enamel and 'A1B' shade resin was used for dentin replacements. Glycerin gel (Air Barrier, GC, Japan) was applied to eliminate the oxygen inhibition layer (Figure 7). All the composite increments were applied with layering technique and polymerized for 10 seconds for each layer according to the manufacturer's instructions. Polishing discs (SofLex, 3M ESPE, USA) were used for marginal, interdental strips (Epitex, GC, Japan) were used for interdental polishing (Figure 8, 9, 10, 11) and only two spiral polishing twists in two different grains (Twist Dia, Kuraray, Japan) were used for labial surface polishing (Figure 12, 13). The patient was called for the follow-up appointments at 3 month (Figure 14, 15), 9 month (Figure 16, 17) and 18 month (Figure 18).
Table 1. The composition of the materials used. 3,9,11,18

\begin{tabular}{|l|l|l|}
\hline & Composition & Manufacturer \\
\hline Estelite Asteria & $\begin{array}{l}\text { Filler: 82 WT\% Supra-Nano Spherical } \\
\text { Filler (200 nm SiO2-ZrO2) } \\
\text { Base resin: Bis-GMA, Bis-MPEPP, } \\
\text { TEGDMA, UDMA }\end{array}$ & $\begin{array}{l}\text { Tokuyama } \\
\text { Dental, Japan }\end{array}$ \\
\hline $\begin{array}{l}\text { Clearfil } \\
\text { Universal } \\
\text { Bond }\end{array}$ & $\begin{array}{l}\text { Bis-GMA, HEMA, ethanol, 10-MDP, } \\
\text { hydrophilic aliphatic dimethacrylate, } \\
\text { colloidal silica, dl-camphorquinone, } \\
\text { silane coupling agent, accelerators, } \\
\text { initiators, water }\end{array}$ & $\begin{array}{l}\text { Koraray } \\
\text { Japan }\end{array}$ \\
\hline $\begin{array}{l}\text { DeTrey } \\
\text { Conditioner 36 }\end{array}$ & Contains 36\% orthophosphoric acid & $\begin{array}{l}\text { Dentsply, } \\
\text { Germany }\end{array}$ \\
\hline $\begin{array}{l}\text { Opalescence } \\
\text { Xtra Boost }\end{array}$ & $\begin{array}{l}\text { Potassium hydroxide 10-20, sodium } \\
\text { fluoride 5-10, potassium nitrate 15-25 }\end{array}$ & $\begin{array}{l}\text { Ultradent, } \\
\text { USA }\end{array}$ \\
\hline
\end{tabular}

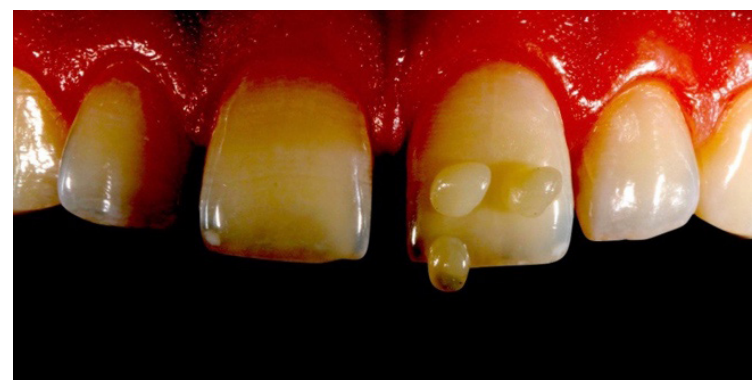

Figure 3. Shade Selection / High contrast

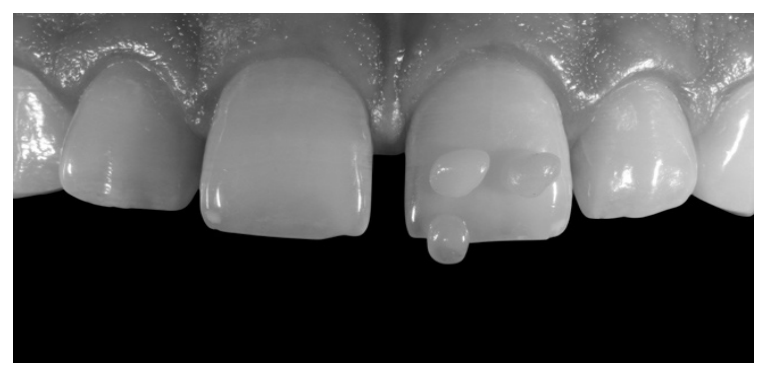

Figure 4. Shade Selection / Black \& White

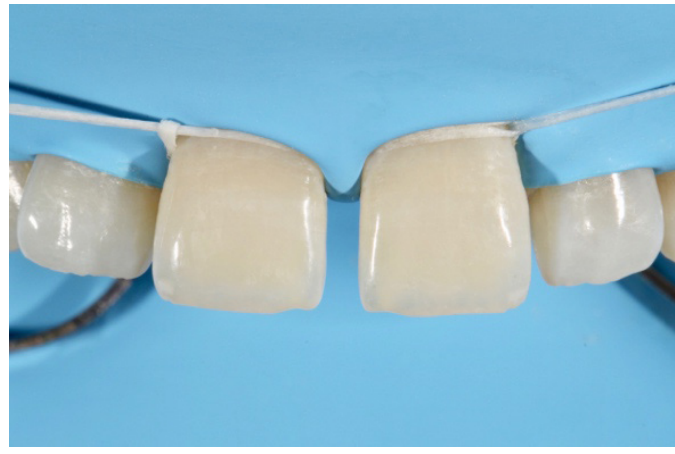

Figure 5. Isolation 


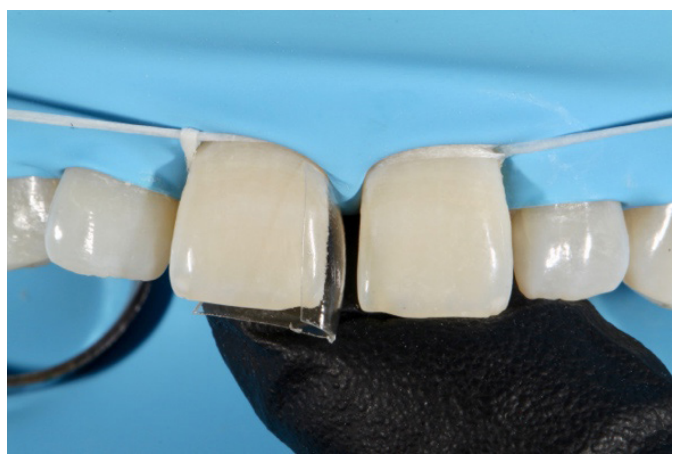

Figure 6. Adaptation of interdental strips

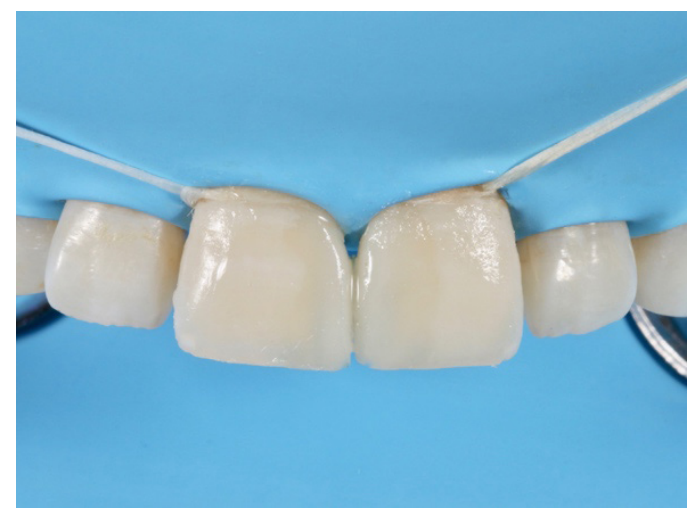

Figure 7. Glycerine application

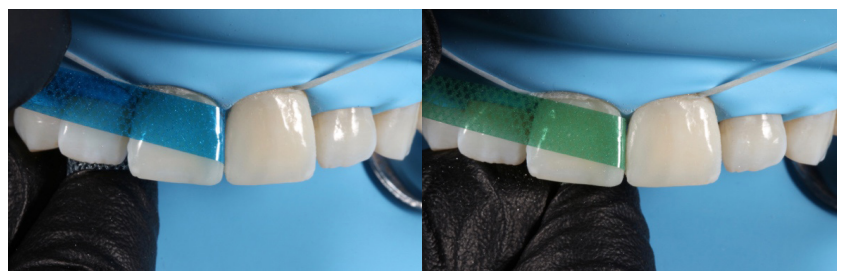

Figure 8. Coarse

Figure 9. Medium

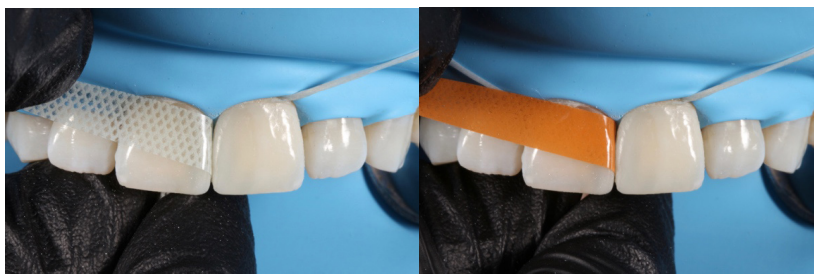

Figure 10. Fine
Figure 11. Extra Fine
Application of interdental polishing strips respectively

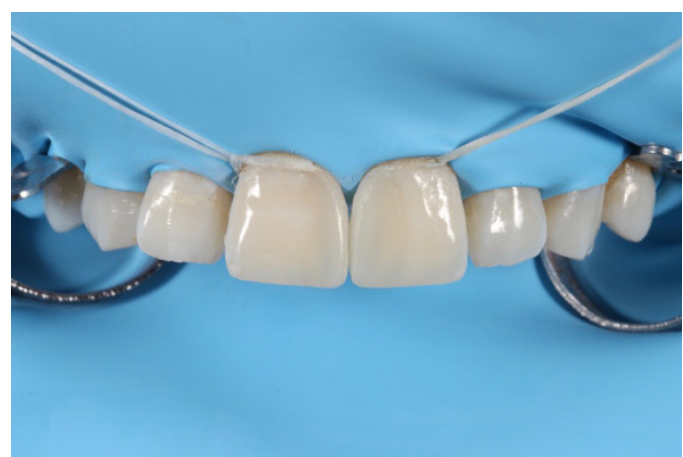

Figure 12. Immediate after the restorations

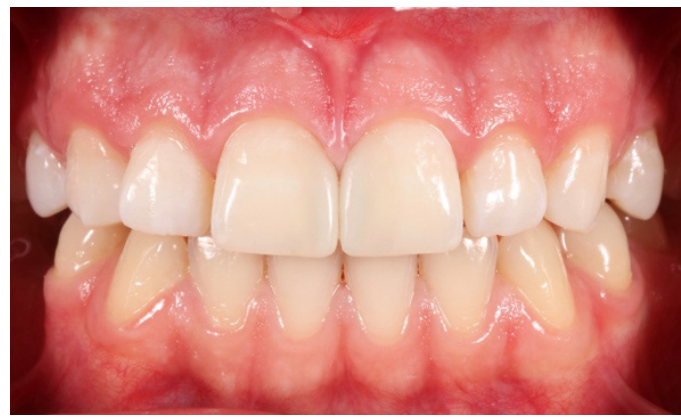

Figure 13. Immediate after the restorations

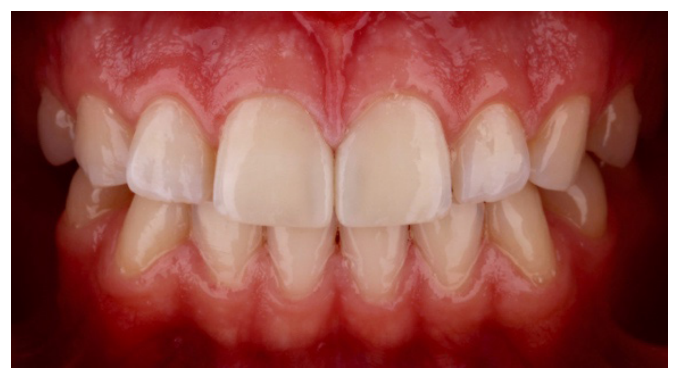

Figure 14. 3 months recall

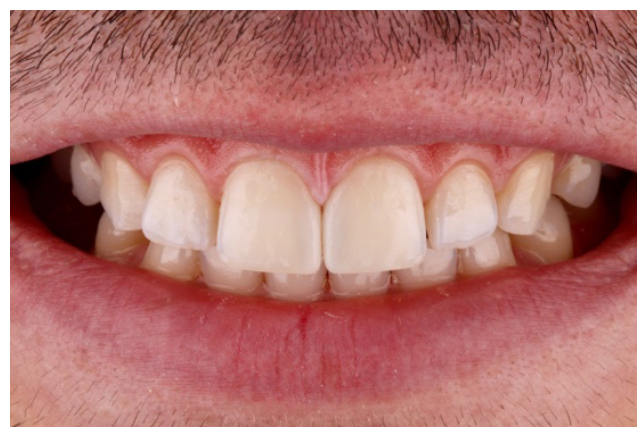

Figure 15. 3 months recall 


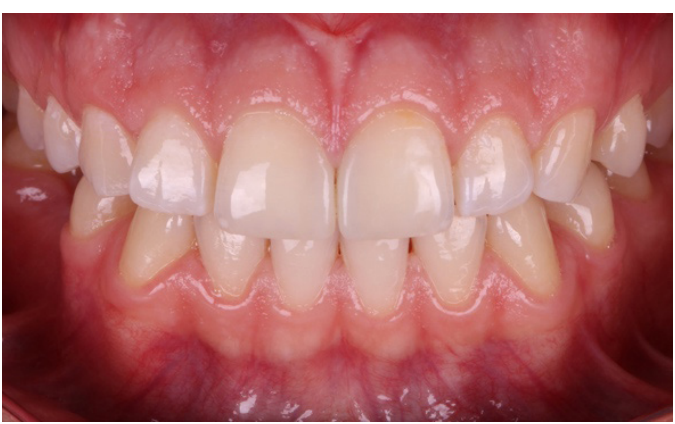

Figure 16. 9 months recall

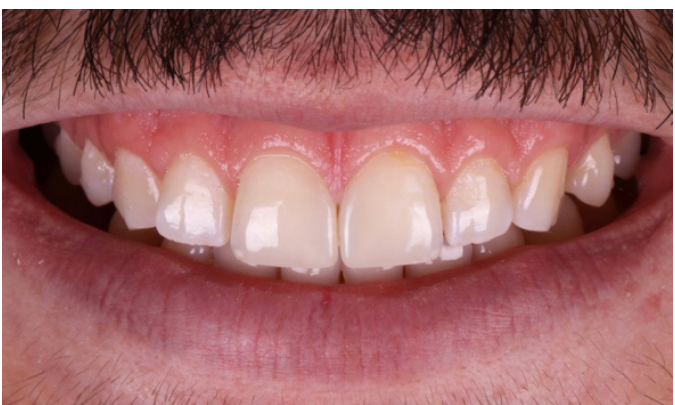

Figure 17. 9 months recall

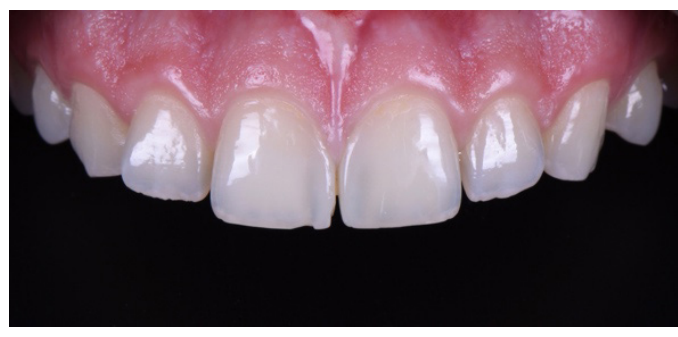

Figure 18. 18 months recall (Fracture Detected)

\section{Results}

The final restorations were evaluated according to the modified United States Public Health Service (USPHS) criterias at 3rd, 9th, 18th months recalls (Table 2).

Restorations were scored as "Alpha", based on clinical examination at $3^{\text {rd }}$ month re-call. At $9^{\text {th }}$ and $18^{\text {th }}$ months controls, marginal discoloration on cervical margin of tooth \#21 was detected. At $18^{\text {th }}$ month surface textures on both teeth were slightly worn away. Also a fracture was observed on mesio-incisal margin of tooth \#11 thus the anatomical form was considered as slightly on contoured. The fracture was corrected at 18 month follow-up and the patient was called for the further follow-ups.

Table 2. Modified USPHS Scores of 3, 9, 18 month-follow-ups ${ }^{20}$

\begin{tabular}{|c|c|c|c|c|c|}
\hline \multirow[b]{2}{*}{ Category } & \multirow{2}{*}{ Score } & \multirow{2}{*}{ Criteria } & \multicolumn{3}{|c|}{ Re-call (Month) } \\
\hline & & & 3 & 9 & 18 \\
\hline RESTORATION & $\begin{array}{l}\text { Alpha (A) } \\
\text { Bravo (B) } \\
\text { Charlie (C) }\end{array}$ & $\begin{array}{l}\text { Restoration is present } \\
\text { Restoration is partially lost } \\
\text { Restoration absent }\end{array}$ & A & A & B \\
\hline MARGINAL INTEGRITY & $\begin{array}{l}\text { Alpha (A) } \\
\text { Bravo (B) } \\
\text { Charlie(C) } \\
\text { Delta (D) }\end{array}$ & $\begin{array}{l}\text { Resin-enamel interface is excellent; restoration closely adapted to the tooth } \\
\text { No crevice is visible at margins } \\
\text { Crevice at margin, enamel exposed } \\
\text { Restoration is mobile, fractured or missing }\end{array}$ & A & A & A \\
\hline MARGINAL DISCOLORATION & $\begin{array}{l}\text { Alpha (A) } \\
\text { Bravo (B) } \\
\text { Charlie (C) } \\
\text { Delta (D) }\end{array}$ & $\begin{array}{l}\text { No discoloration on the margin between the restoration and the tooth structure } \\
\text { Slight staining can be polished away } \\
\text { Obvious staining cannot be polished away } \\
\text { Gross staining }\end{array}$ & A & B & B \\
\hline ANATOMICAL FORM & $\begin{array}{l}\text { Alpha (A) } \\
\text { Bravo (B) } \\
\text { Charlie (C) } \\
\text { Charlie (C) }\end{array}$ & $\begin{array}{l}\text { Restoration continuous with existing anatomical form and margins } \\
\text { Restoration is slightly overcontoured or oncontoured } \\
\text { Restoration is undercontoured, dentin or base exposed } \\
\text { Restoration is missing }\end{array}$ & A & A & B \\
\hline SECONDARY CARIES & $\begin{array}{l}\text { Alpha (A) } \\
\text { Charlie (C) } \\
\end{array}$ & $\begin{array}{l}\text { No evidence of caries contiguous with the margin of the restoration } \\
\text { Caries evident contiguous with the margin of the restoration }\end{array}$ & A & A & A \\
\hline SURFACE TEXTURE & $\begin{array}{l}\text { Alpha(A) } \\
\text { Bravo (B) } \\
\text { Charlie (C) } \\
\text { Delta (D) } \\
\end{array}$ & $\begin{array}{l}\text { Smooth surface } \\
\text { Slightly rough or pitted } \\
\text { Rough, cannot be refinished } \\
\text { Surface deeply pitted, irregular grooves }\end{array}$ & A & A & B \\
\hline $\begin{array}{l}\text { SHADE } \\
\text { MATCH }\end{array}$ & $\begin{array}{l}\text { Alpha (A) } \\
\text { Bravo (B) } \\
\text { Charlie (C) } \\
\text { Delta (D) } \\
\end{array}$ & $\begin{array}{l}\text { Restorations matches the shade and translucency of adjacent tooth structure } \\
\text { Discoloration between restoration and tooth structure within the normal range of tooth } \\
\text { Discoloration between restoration and tooth structure outside the normal range of tooth } \\
\text { Unacceptable color, shade and translucency }\end{array}$ & A & A & A \\
\hline POSTOPERATIVE SENTITIVITY & $\begin{array}{l}\text { Alpha (A) } \\
\text { Bravo (B) } \\
\text { Charlie (C) }\end{array}$ & $\begin{array}{l}\text { No postoperative sensitivity } \\
\text { Postoperative sensitivity } \\
\text { Postoperative sensitivity with treatment need }\end{array}$ & A & A & A \\
\hline
\end{tabular}




\section{Discussion}

Al-Rubayee reported midline diastema incidence as $28 \%$, in maxillary $22.5 \%$, in mandibular $2.3 \%$, and in both arches $3.2 \%)$. The majority of females $(87.5 \%)$ found with median diastema is one of the reasons of un-esthetic outlook. Midline diastema often occurs with band of thick heavy fibrous tissue lies between central incisors. ${ }^{8}$ Dental material arch length discrepancy has a multifactorial etiology such as; missing teeth, microdontia, macrognathia, peg-shaped laterals, thumb sucking, tongue thrusting, soft tissue and hard tissue pathologies (cysts, tumors and odontomas). ${ }^{12}$ The diastemas can be closed restoratively, orthodontically or with combination of both. Clinical parameters such as number and size of the diastemas, play a key role in that. ${ }^{7}$ The restorative approach includes direct composite and indirect ceramic treatments. ${ }^{2}$ Recent composite resin materials have improved mechanical and optical properties, hence are aesthetic, stable and have a longevity of adhesion mainly to enamel. ${ }^{8}$ The physical and chemical improvements have also optimized the color stability and improved the wear resistance of the composite resins. ${ }^{8,10}$ Diastema closure with direct composite resins is a clinically proven treatment procedure today. ${ }^{6}$ Moreover, in this method also no preparation is needed if only proper enamel adhesion is caried out. ${ }^{6}$

In this case, prep-less resin composite restoration was selected as the treatment method for a major diastema closure. Composite layering concept including the use of two separate composite shades was considered to restore the natural alike tooth anatomy. ${ }^{5}$ A supra-nano inorganic filler containing resin composite, Estelite Asteria was used to emulate the natural dental layers. Improved physical properties (inorganic filler silica-zirconia 71\% volume / $82 \%$ weight; flexural strength $101 \mathrm{MPa}$ ) of this resin have possibly increased the durability of the restorations. ${ }^{13}$ That also increased the resistance to surface wear though slight surface abrasions on both restorations were detected at $18^{\text {th }}$ month recall which are predictable for any composite resin restoration in such time period. The fracture of the restoration on tooth \#11 at $18^{\text {th }}$ month was due to an acute trauma while chewing as the patient explained, which is also acceptable. As one of the main advantages of composite resin restorations is direct easy repair, the fracture was corrected in a single visit by using composite repair protocols. ${ }^{19}$ Very small sized fillers (inorganic filler size, 200nm) improved the polishability of the resin hence decreases the surface roughness. This explains the high, long-term resistance to discoloration under the conditions of the case presented.

In dentistry, three external bleaching techniques are used: night guard (home) bleaching, in office bleaching and over the counter whitening products. ${ }^{15}$ When compared to night guard bleaching, in office bleaching technique has many advantages such as handling by dentist, avoidance of soft tissue exposure, reduced treatment time and immediate results. ${ }^{16}$ This technique requires the application of hydrogen peroxide in high concentration for a short time. ${ }^{17}$ Office bleaching technique was used in this study.

A fracture on tooth\# 11 was corrected at 18 month follow-up by using standard composite repair protocols. ${ }^{19}$ Air abrasion, silane, adhesive agent and composite resin (A1B, NE) were used respectively for the repair (Figure 19, 20).

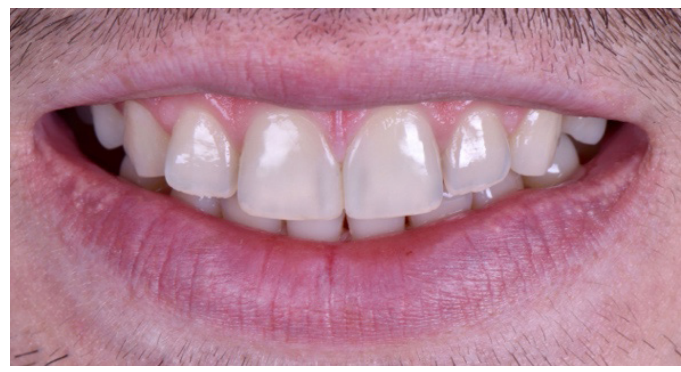

Figure 19. Correction of the Fractured Restoration

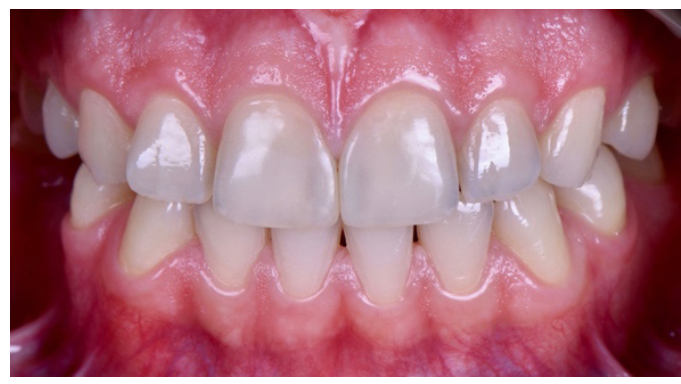

Figure 20. Correction of the Fractured Restoration

The patient's aesthetic problem was resolved with a conservative way including office bleaching and direct resin composite restorations without any preparations. At 18 month recall except a small mesio-incisal fracture on tooth \#11, the modified USPHS scores of the restorations were considered as acceptable. ${ }^{20}$ The fracture was repaired at the same visit and the patient was called for further follow-ups. 


\section{References}

1. Elfadel II, Abuaffan AH. Prevalence and Etiology of Midline Diastema among Sudanese University Students. Indian Journal of Dental Education. 2016;9(1):15-20 Prevalence and Etiology of Midline Diastema among Sudanese University Students. Indian Journal of Dental Education.

2. Prabhu R, Bhaskaran S, Geetha Prabhu KR, Eswaran MA, Phanikrishna G, Deepthi B. Clinical evaluation of direct composite restoration done for midline diastema closure long-term study. Journal of pharmacy \& BioAllied Sciences. 2015;7(2):559-562 https://www.ncbi.nlm.nih.gov/pmc/ articles/PMC4606659/

3. AIDA A, N Masatoshi, S Naoko, K Yukinori, M.F. Richard, T Junji. Effect of enamel margin con guration on color change of resin composite restoration. Dental Materials Journal. 2016;35(4):675-683 AIDA A, N Masatoshi, S Naoko, K Yukinori , M.F. Richard, T Junji. Effect of enamel margin con guration on color change of resin composite restoration. Dental Materials Journal. 2016; 35(4):675-683

4. Korkut B. Emulating Natural Morphology In Anterior Crown Fractures: Two Years Follow-up Report. Adv Dent \& Oral Health. 2017;6:(1):1-5

5. Aslam A, Ahmed B, A Azad, O Nida, N Maleeha. Layers to a beautiful smile: composite resin stratification. Pakistan Oral \& Dental Journal. 2016;36(2):335-340 https://search. proquest.com/docview/181.007.1159?pq-origsite=gscholar

6. Bakır EP, Yıldırım ZS, Bakır S. The anterior polidiastema closure with direct composite resin restorations: 5 case report. Journal of dental faculty Ataturk University. 2016;15:18-25

7. Araujo E M, Fortkamp S. Closure of Diastema and Gingival Recontouring Using Direct Adhesive Restorations: A Case Report. Journal of Esthetic and Restorative Dentistry 2009; 21(4):229-240

8. Katsarou T, Antoniadou M, Papazoglou E. Effectiveness and optical illusions applied on a single composite resin veneer for the diastema closure of maxillary central incisors. The International Journal of Esthetic Dentistry. 2017:12:42-59

9. Chen C, Niu LN, Xie H, Zhang ZY, Zhou LQ, Jiao K, Chen JH, Pashley DH, Tay FR. Bonding of universal adhesives to dentine old wine in new bottles? Journal of dentistry Elsevier. 2015:43(5):525-36
10. Korkut B, Yanıkoğlu F, Tağtekin D. Direct Midline Diastema Closure with Composite Layering Technique: A One-Year Follow-Up. Hindawi Publishing Corporation in Dentistry. 2016;2016:1-5

11. Gezawi ME, Haridy R, Elazm EA, Al-Harbi F, Zouch M, Kaisarly D. Microtensile bond strength, 4-point bending and nanoleakage of resin - dentin interfaces: Effects of two matrix metalloproteinase inhibitors. Journal of the Mechanical Behavior of Biomedical Materials. 2018;78:206-213

12. Nainar SM, Gnanasundaram N. Incidence and etiology of midline diastema in a population in south India (Madras) Angle Orthodontist. 1989;59:277-82

13. Kano Y, Nakajima M, Aida A, Seki N, Foxton RM, Tagami $\mathrm{J}$. Influence of enamel prism orientations on color shifting at the border of resin composite restorations. Dental Materials Journal 2018;37(2):341-349

14. Goyal A, Nikhil V, Singh R. Case Report: Diastema Closure in Anterior Teeth Using a Posterior Matrix. Hindawi Publishing Corporation

15. Heymann HO. Tooth whitening: facts and fallacies. Br Dent J 2005; 198(8):514

16. Luk K, Tam L, Hubert M. Effect of light energy on peroxide tooth bleaching. The Journal of the American Dental Association 2004;135(2):194-201

17. Alharbi A, Ardu S, Bortolotto T, Krejci I. In-office bleaching efficacy on stain removal from CAD/CAM and direct resin composite materials. J Esthet Restor Dent. 2018;30:51-58

18. Dominguez JA, Bittencourt B, Michel M, Sabino N, Gomes Joc, Gomes Omm. Ultrastructural Evaluation of Enamel After Dental Bleaching Associated With Fluoride. Microschopy research and technique. 2012;75(8):1093-1098

19. Tabatabaei HM, Alizade Y, Taalim S. Effect of Various Surface Treatment on Repair Strength of Composite Resin. 2004;4(1):5-11

20. Lempel E, Lovasz B. V, Meszarics R, Jeges S, Toth A, Szalma J. Direct resin composite restorations for fractured maxillary teeth and diastema closure: A 7 years retrospective evaluation of survival and influencing factors. Dent Mater. 2017;33(4), 467-476. 